\title{
The Role of El Nino Variability and Peatland in Burnt Area and Emitted Carbon in Forest Fire Modeling
}

\author{
Ida Bagus Mandhara Brasika ${ }^{*}$ (D)
}

\section{AFILIATION}

Faculty of Marine Sciences and Fisheries, Universitas Udayana

* Correspondence: mandharabrasika@unud.ac.id

RECEIVED 2020-07-12

ACCEPTED 2021-12-15

COPYRIGHT @ 2022 by Forest and Society. This work is licensed under a Creative Commons Attribution 4.0 International License

\begin{abstract}
This study was conducted to model fire occurrence within El Nino variability and peatland distribution. These climate and geographical factors have a significant impact on forest fires in tropical areas such as Indonesia. The re-analysis dataset from ECMWF was observed with respect to climate characteristics in Indonesian El Nino events. The INFERNO (INteractive Fire and Emission algoRithm for Natural envirOnments) was utilized to simulate fires over Borneo Island due to its capability to simulate large-scale fires with simplified parameters. There were some adjustments in this INFERNO model, especially for peat fire as peatland has a significant impact on fires. The first was the contribution of climate to the peat fire which is represented by long-term precipitation. The second was the combustion completeness of peat fire occurrence that is mainly affected by human-induced peat drainage. The result of the model shows that El Nino variability mainly affected peat fires but was unable to well simulate the above-ground fire. It increased the burnt area during strong El Nino but overestimated the fires during low/no El Nino season due to lack of peat fire ignition in the calculation. Moreover, as the model did not provide peat drainage simulation, it underestimated the carbon emission. This model has shown promising results by addressing key features in limited input data, but improving some simulations is necessary for regulating weak/no El Nino conditions and carbon combustion of peat fire.
\end{abstract}

\section{KEYWORDS}

carbon combustion; peat soil; drainage; climate change; tropical forest

\section{INTRODUCTION}

Fires have caused massive loss of tropical forests, but our ability to predict future fire impacts rests on our ability to model fire regimes (Hantson et al., 2016). In the tropical regions, El Nino has played a major role in the climate system which is accompanied with massive change of carbon cycle caused by forest fires (Liu et al., 2017). Future climate change is mainly induced by atmospheric greenhouse gases, so a fire model that is able to simulate the key processes efficiently and connect to the carbon process is needed (Friedlingstein et al., 2001; Friedlingstein et al., 2003).

However, climate factors like El Nino are not the only major factors; geographical conditions, such as highly distributed peatlands, have to be considered as it is the dominant contributor for carbon dioxide emission (Parish et al., 2008). Peat fires occur because they are the easiest way to clear peatlands by drainage. In this practice, the climatic factor is significant to determine the spread of fire. The climate can affect the dry period or drought, in which peatlands can be easily ignited by a small fire (Li et al., 2013). Then, a peat fire creates a long fire regime as it burns below the ground surface and it is almost impossible to find the source of the fire.

The current fire models are developed by two main streams. The top-down model is based on the statistical relationship between key variables (aspects of fire regime, usually burned areas), while the bottom-up model represents small-scale fire 
dynamics (simulating a single fire). These two concepts have different advantages and disadvantages based on the aim of the research.

The top-down fire model can capture the potential burned areas and the emission of the fire. Therefore, potential damage can be predicted, and management strategy can be developed based on this fire model. In terms of fire modelling, the El Nino forecast might be the most realistic to be considered in estimating the extent and magnitude of fire activity due to its capacity to drive the climate condition (Wooster et al., 2012). However, the complexity of nature should be simplified to approach the most realistic result with the least resources. The INFERNO (INteractive Fire and Emission algoRithm for Natural envirOnments) Fire Model is developed with a simplified parameterization for fire counts that can generalize the complexity of nature (Mangeon et al., 2016). It performs well at a low latitude when applied on large scales of fire occurrence. However, this model is unable to capture small-scale fire dynamics.

To understand how this fire model can simulate the impact of El Nino and peatland, the Borneo Forest will be a comprehensive example to focus on. The Borneo rainforest is a crucial forest area in the world, mostly in tackling climate change, because it is the largest rainforest in Southeast Asia/Equatorial Asia. Unfortunately, a massive deforestation process remains a classic problem in this area (Achard et al., 2002; Fuller, 2006; Trigg et al., 2006). The significance of Borneo is due to its timber species which are of commercial benefit. These are in the coastal lowlands of Borneo that are covered by vast areas of peat swamp forests (Rieley \& Page, 2005). As fire is still a huge factor of degradation and deforestation in tropical South America and Southeast Asia, Borneo is also impacted by this acceleration of fire (Siegert et al., 2001; Page et al., 2002; Cochrane, 2003).

Rainfall and the temperature are considerably high in the tropical climate like Borneo due to its geographical location between two oceans and two continents (Langner \& Siegert, 2007). The main factor of the Indonesian climate is the monsoon, which is an annual event, and controls the seasons in Indonesia, namely the wet and dry seasons. Another important climate event is the El Nino Southern Oscillation (ENSO), which has a longer temporal pattern and is not as frequent as the monsoon, i.e., occurring every 2 to 7 years. Otherwise, ENSO has a major impact on the dryness in Indonesia. The El Nino phenomenon has large-scale and short-term impacts on the elements of climate such as precipitation (precipitation dramatically drops to a lower level in a few months). This phenomenon significantly affects the magnitude of fires because it can raise fire activity that is a result of human ignition, agricultural preparation practices, and land cover changes that occur every year in Borneo (Wooster et al., 2012) (Field et al., 2009). Thus, El Nino is claimed to be the cause of massive forest fires.

To understand the complexity of the connection between climate phenomena, geographical conditions, and fire events in Borneo, a model to simulate the condition is needed. The model needs data from the climate and vegetation simulation due to the obvious link between fires, vegetation, and climate, so the climate change results in the change of fire (Hantson et al., 2016).

The ability of the fire model to simulate smaller-scale and tropical regions needs to be examined further in this paper. This is to show to what extent a fire model with limited sources is capable of simulating the role of the key drivers of tropical forest fires (El Nino and peatland). What is the spatial-scale limit for a top-down fire model? 
How is a fire model able to simulate a fire, which is driven by climate variability and geographical conditions?

\section{MATERIALS AND METHODS}

The research site is located on Borneo Island, which is one of the largest islands with tropical forests. This island has experienced several massive forest fires during the El Nino event (Figure 1) which can be clearly seen on satellite images taken by MODIS (Moderate Resolution Imaging Spectroradiometer). Moreover, fire clearing is commonly practiced with peat drainage to accelerate the process. Thus, the massive fires in Borneo island are relevant to represent the role of El Nino and peatland in the forest-fire model.

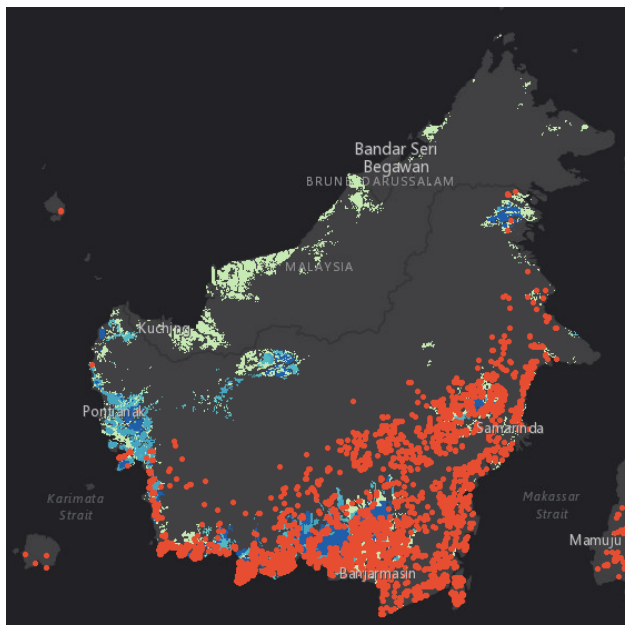

Figure 1. Illustration of the fire counts on Borneo island during a strong El Nino event in 2015 based on MODIS datasets

The model is developed from the previous model by Mangeon et al. (2016) who constructed INFERNO based on Pechony \& Shindell (2009) fire counts. However, the simulation is focused on an El Nino year because it has a significant impact on forest fires in the tropics. The INFERNO model uses a simplified parameterization that enables it to simulate large-scale fire variability with considerably limited data. It only needs data on the precipitation, temperature, humidity, and indirect vegetation for flammability. Then, fire ignitions are simulated based on lightning and/or anthropogenic information. The general scheme of INFERNO can be seen at Figure 2. However, INFERNO has several limitations. It is not suitable for simulating detailed features of fire such as ignition, spread, and extinction explicitly. Moreover, previous research (Mangeon et al., 2016) also shows that it underestimates variability in emissions.

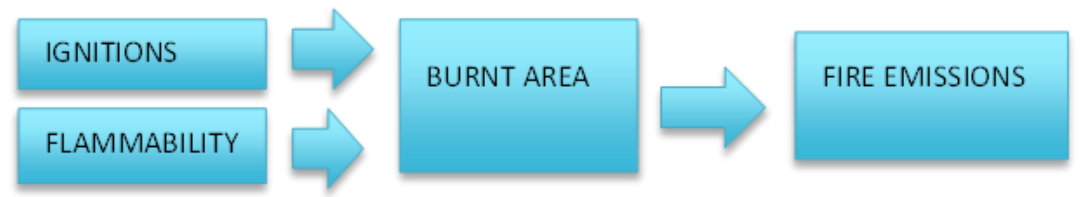

Figure 2. Scheme of the INFERNO Fire Model (Mangeon et al., 2016) 
As with the previous model by (Mangeon et al., 2016), this model also elaborates the JULES (Joint UK Land Environment Simulator) model on carbon fluxes and vegetation dynamics (Best et al., 2011; Clark et al., 2011). INFERNO utilizes soil moisture from JULES as the balance between precipitation and extraction by evapotranspiration and runoff. The INFERNO formulas are shown in Appendix A. This study extends the model by simulating the effect of peat and carbon combustion.

The JULES-INFERNO model was examined under the condition of strong El Nino because an El Nino year drives drought conditions which strongly influence tropical fires. Then, adjustments in peat fire and combustion completeness were considered to produce a more accurate model.

To pursue the role of El Nino and peatland, some adjustments were necessary in this research. First, the default JULES-INFERNO was run on an El Nino year over Borneo to understand the current state of models. Then, modification was made by adding the peatland burnt area and using the emission calculation, which is proposed by Li et al. (2013). The model involved a peat fire due to the unpredicted effect of peat on the fire regime, which is mainly affected by long-term precipitation in terms of climate factors. Moreover, the risk of fire is higher in the lower mineral content like peat soil (Frandsen, 1997). Long-term precipitation was examined in several periods ranging from 30 to 90 days. Last, modification was tuned up from the peat fire combustion. Combustion completeness of peat fires is modified by van der Werf et al. (2006) in the loss of carbon soil schemes in human-induced drainage of peat soil. The low combustion represented the natural conditions of peat while the high combustion occurred due to peat drainage practices by humans. These are illustrated below (see Figure 3).

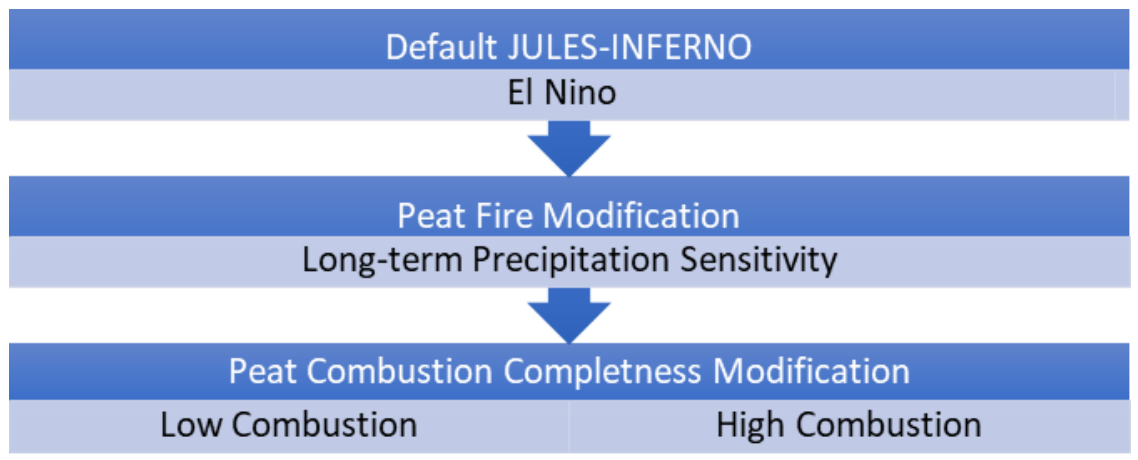

Figure 3. The diagram of the methodology of the modification of the JULES-INFERNO fire model

The fire model INFERNO will not simulate the behavior of a single fire but will estimate fire occurrence during high El Nino. Meteorological data on such elements as precipitation, humidity, temperature, and soil moisture were obtained from the European Centre for Medium-Range Weather Forecast (ECMWF) dataset, specifically the ERA-Interim. ERA-interim is a reanalysis dataset that provides a 6-hourly analysis of upper-air parameters including those of the troposphere and stratosphere. The advantages of the reanalysis dataset are that the data provides a multivariate, spatially complete, and coherent record of the global atmospheric circulation (Dee et al., 2011). Then, some data related to peat were obtained from the Oak Ridge National Laboratory Distributed Active Archive Center (ORNL DAAC) for Biogeochemical 
Dynamics (Stocker et al., 2017). The other prescribed data were produced by the same dataset that is used in "Developing and evaluating a global model for landscape fires" (Mangeon, 2016), "Land use \& population density" (Hurtt et al., 2011), CO2 concentration (Le Quéré et al., 2015), and Lightning (Christian et al., 2003). Data on long-term precipitation for including the climatic factor in the peat fire calculation were not available, so the data were calculated based on the ERA-Interim total precipitation dataset with the Climate Data Operator (CDO) tool. These results would be verified with the GFED dataset which includes small fires. This dataset was chosen as it considered deforestation, degradation, peatland fires, and agricultural waste burning (Giglio et al., 2013). The last set of data is the Oceanic Nino Index which was obtained from the National Weather Service (2015). The summary of the datasets is shown below (see Table 1):

Table 1. List of datasets as the input and verification data

\begin{tabular}{|c|c|c|c|c|}
\hline No & Data & Variables & Source & \\
\hline 1 & Driver data & $\begin{array}{ll}- & \text { Total precipitation } \\
- & \text { U-wind } \\
- & \text { V-wind } \\
- & \text { Temperature } \\
- & \text { Specific humidity }\end{array}$ & $\begin{array}{l}\text { ECMWF ERA- } \\
\text { Interim }\end{array}$ & \\
\hline 2 & Peatland & $\begin{array}{ll}\text { - } & \text { Fraction of peat } \\
\text { - } & \text { Peat Soil Carbon }\end{array}$ & ORNL-DAAC & \\
\hline 3 & $\begin{array}{l}\text { Prescribed } \\
\text { Data }\end{array}$ & $\begin{array}{ll}\text { - } & \text { Fraction of } \\
& \text { Agriculture \& } \\
& \text { Population Density } \\
- & \mathrm{CO}_{2} \text { concentration } \\
- & \text { Lightning }\end{array}$ & $\begin{array}{ll}- & \text { HYDE } \\
\text { dataset } \\
\text { - } & \text { Global } \\
\text { carbon } \\
\text { budget } \\
\text { - } \quad \text { LIS-OTD }\end{array}$ & \\
\hline 4 & $\begin{array}{l}\text { Long-term } \\
\text { precipitation }\end{array}$ & $\begin{array}{l}\text { - } \quad \begin{array}{l}\text { An average of } 60 \\
\text { days }\end{array} \\
-\quad \begin{array}{l}\text { An average of } 30 \\
\text { days }\end{array} \\
\text { - } \quad \begin{array}{l}\text { An average of } 90 \\
\text { days }\end{array}\end{array}$ & $\begin{array}{l}\text { ECMWF ERA- } \\
\text { Interim }\end{array}$ & $\begin{array}{l}\text { Re-calculated by } \\
\text { Climate Data } \\
\text { Operator (CDO) }\end{array}$ \\
\hline 5 & $\begin{array}{l}\text { Verification } \\
\text { Data }\end{array}$ & $\begin{array}{ll}- & \text { Burnt Area } \\
- & \text { Carbon Emission } \\
- & \text { El Nino Index }\end{array}$ & $\begin{array}{l}\text { GFEDv4.1s } \\
\text { Climate } \\
\text { Prediction Cer }\end{array}$ & \\
\hline
\end{tabular}

All of these datasets were considered to calculate Burnt Area and Emitted Carbon as these both are able to show the impact of El Nino and peat soil in the fire model. Burnt Area is highly related to long-term precipitation, which is affected by $\mathrm{El}$ Nino, while fire in peat soil will contribute massively to Emitted Carbon in the model because peat contains a huge amount of carbon.

\subsection{Burnt Area Peatland (BA $\left.\boldsymbol{A}_{\text {peat }}\right)$}

The burnt area in the peatland (Equation (1)) relies on the factor of long-term precipitation because peat fire has a characteristic of burning under the surface of soil, so long memory of precipitation can represent water availability in peat soil. The burnt area is determined as follows:

$$
B A_{\text {peat }}=c \boldsymbol{f}_{\text {cli.p }} \boldsymbol{f}_{\text {peat }}\left(1-\boldsymbol{f}_{\text {sat }}\right)
$$


where $C$ (per timestep) is constant to match the burnt area to the real conditions by using the inverse method, and here in the tropical peat the $c=8.2 \times 10^{-4} \mathrm{~h}^{-1}$. The $f_{\text {cli.p }}$ represents the factor of climate (precipitation) affecting the burnt area (Equation (2)), and this variable will be examined in this research to find the optimum long-term precipitation that can determine the actual burnt area. The $f_{\text {peat }}$ is the fraction of the peatland area in the grid cell. The peatland data were obtained from NASA Earthdata which provides a time series of global peatland carbon balance and carbon dioxide emissions from land use change throughout the Holocene (the past 11,000 years), as published in Stocker et al., 2017. Quantification was done using the global model simulations with the LPX-Bern model hindcasting the dynamics of past peatland distribution and carbon balance (based on Stocker et al., 2014). Unfortunately, the most recent data on peatland cover are from the year 1985. The $f_{\text {sat }}$ is the fraction of the saturated area in the grid cell with the water table at the surface or at a higher level. This variable is derived from the land use model (JULES) output where the variable represents the area of peat that is impossible to burn.

$$
f_{c l i, p}=\max \left[0, \min \left(1, \frac{4-P_{60 d}}{4}\right)\right]^{2}
$$

(Equation 2)

As mentioned previously, the factor of climate is taken into account, in terms of long-term precipitation. Li et al. (2013) proposed the average 60-day precipitation $\left(P_{60 d}\right)$ as the best approach to represent water memory in the soil for tropical peat soil (Equation (2)). For further development of this research, the robustness of this variable will be examined by varying the days of precipitation. The spontaneous precipitation from JULES output is also considered to test the sensitivity of the variable.

\subsection{Emitted Carbon Peatland $\left(\boldsymbol{E} \boldsymbol{C}_{\text {peat }}\right.$ )}

Based on the approach proposed by Li et al. (2013), the emitted carbon ( $\mathrm{kg} \mathrm{C} \mathrm{m}$ 2) from the burnt peat (Equation (3)) can be formulated as follows:

$$
E C_{\text {peat }}=B A_{\text {peat }} C_{\text {soil }} C C_{\text {peat }}
$$

(Equation 3)

The $B A_{\text {peat }}$ is the area of burnt peat as mentioned in the equation (3), while $C_{\text {soil }}$ represents the carbon content ( $\mathrm{g} \mathrm{C} \mathrm{m-2)} \mathrm{of} \mathrm{the} \mathrm{peat} \mathrm{soil} \mathrm{which} \mathrm{is} \mathrm{obtained} \mathrm{from} \mathrm{the}$ global model data published in Stocker et al. (2014). The $C C_{\text {peat }}$ is the combustion completeness of the burnt peat which is $18 \%$ for tropical peatlands (Page et al., 2002). This percentage is applied for peat in natural conditions, but in human-induced drainage, a minimum of $50 \%$ of soil carbon is released (van der Werf et al., 2006). This combustion completeness should be varied in different peat soil conditions, especially with different soil moisture and mineral contents. However, these details might not be needed in this regional-scale model.

\section{RESULTS}

\subsection{El Nino Year Simulation (Default INFERNO)}

The year 2015 was chosen to show the contribution of El Nino to tropical fires due to very strong El Nino activities in this year. The model shows that the global emitted carbon has an opposite pattern to that of the El Nino event. The higher amount of carbon emitted was during weak El Nino, while the lower amount of carbon emitted was during very strong El Nino. The model has shown low levels of emissions as indicated in Figure 4, where it can be seen that the highest amount of carbon 
emission is only under $0.25 \times 10^{-10} \mathrm{~kg} \mathrm{C} \mathrm{m}^{-2} \mathrm{~S}^{-1}$.

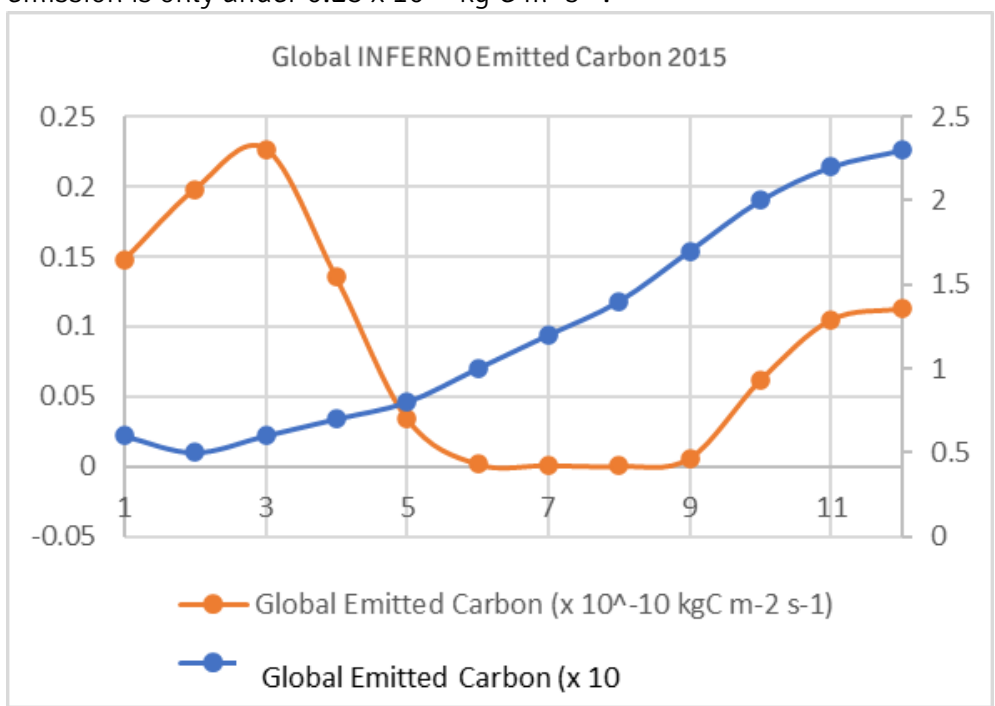

Figure 4. The temporal variability of INFERNO total global carbon emissions in 2015

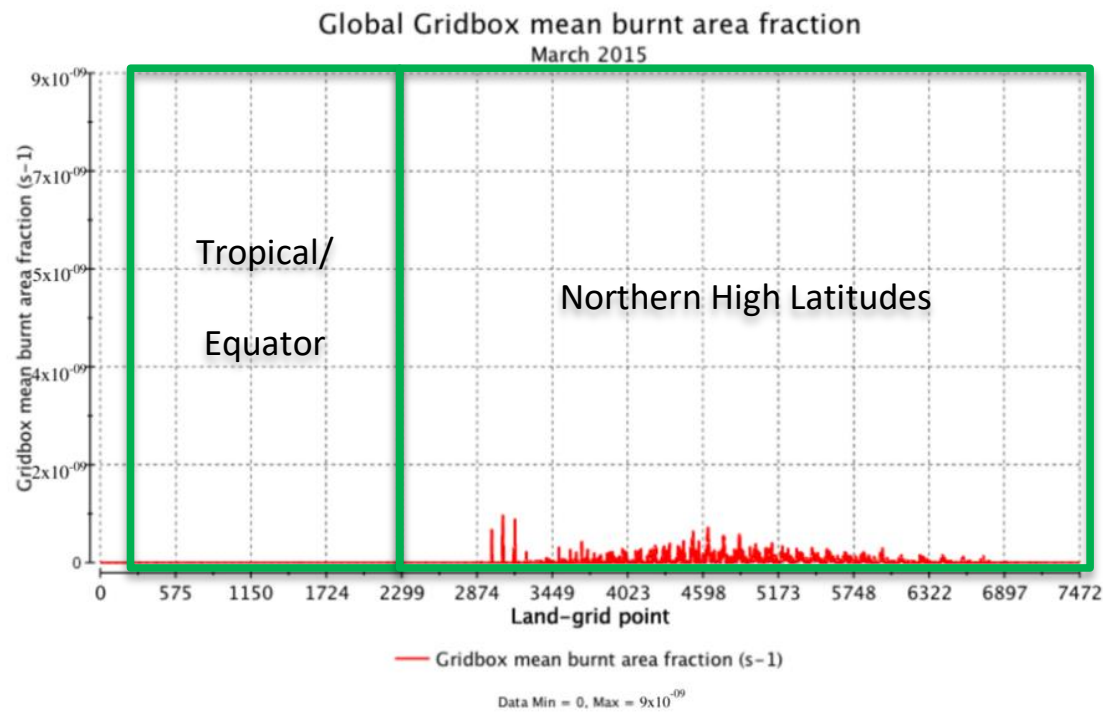

Figure 5. The mean burnt area fraction in the highest emission month (March 2015). The land-grid point is divided into two areas, namely the tropical/equatorial regions and the northern high latitudes. Every land-grid point represents an area of land with a size of about $1.85 \times 1.25$ degrees.

Unfortunately, this global scenario does not well represent tropical forest fires as the model has failed to simulate fire occurrence in the equatorial area as shown in Figure 5. Lack of peat fires in the default JULES-INFERNO model might be the main factor. The $\mathrm{x}$-axis is the Land-grid point with every point representing an area of $1.85^{\circ}$ Brasika (2022) 
$x 1.25^{\circ}$ degrees in the land. It is divided into two areas, i.e. the equatorial Asia (5602613 land grid point) and the northern high latitudes (2614-7472 land grid point). The amount of burnt area in the Tropical/Equatorial regions (between $23.5^{\circ} \mathrm{S}-23.5^{\circ} \mathrm{N}$ ) is zero in any land-grid point, even in March 2015 where the highest global emission occurred. Thus, the seasonal pattern in Figure 4 likely only represents fires in the northern high latitudes (more than $23.5^{\circ} \mathrm{N}$ ).

\subsection{Peat Fire Calculation Based on Long-term Precipitation}

\subsubsection{Inclusion of peat}

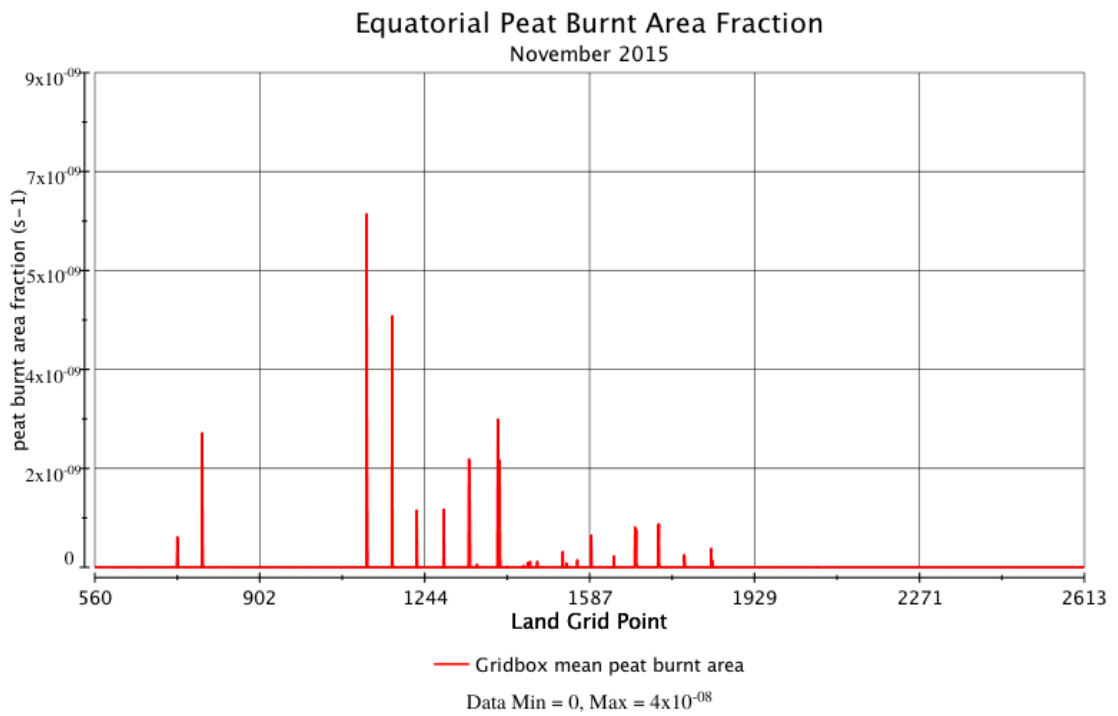

Figure 6. The burnt area of peat in the equatorial region (between 23.5 south and 23.5 north) in the high El Nino month. As the above-ground fire is zero, this also represents the total burnt area.

Since, as mentioned in the previous section, the default JULES-INFERNO model is unable to simulate emitted carbon in tropical regions, the peat fire calculation is added in this section. The tropical peat calculation (based on Li et al., 2013) in the equatorial land-surface has significantly affected the burnt area in the INFERNO model. This simulation utilizes the 60-day (medium) long-term precipitation as the climatic factor and $18 \%$ combustion completeness to represent the natural conditions. The equatorial land is located between 560 and 2613 Land-grid points. The result in Figure 6 illustrates that the amount of burnt area in the tropical area is significant in the high El Nino Index month (November 2015). The burnt area could reach $4 \times 10^{-08} \mathrm{~S}^{-1}$ (much higher than the burnt area without peat calculation). The model modification improves the burnt area simulation.

\subsubsection{The precipitation variation variable as the climatic factor $\left(f_{\text {cli.p }}\right)$}

The main driver of peat fire is the climatic factor which is long-term precipitation. Li et al., (2013) defined the average precipitation over 60 days as the best approach, but in this research the long-term precipitation is varied into 30 days $\left(P_{30 d}\right)$ and 90 days $\left(P_{90 d}\right)$ to find the sensitivity and optimum result. Figure 7 portrays 
the burnt area of Borneo in September 2015. The $P_{60 d}$ and $P_{90 d}$ resulted in the same pattern, which shows that the burnt area appears very lightly (less than 0.007 fraction/month) in the south of Borneo, but the $P_{30 d}$ produced a higher amount of burnt area in the north-west to the south region. The $P_{30 d}$ has shown completely different patterns from the other long-term precipitation scenarios and a much higher amount of burnt area. However, the maximum burnt area of $P_{30 d}$ is 0.04 fraction/month while the verification dataset from GFEDV4.1s showed that the maximum burnt area in South Kalimantan could reach 0.45 fraction/month. Thus, adding peat fire calculation affects the ability of the fire model in describing fire occurrence in tropical regions, although the magnitude is lower.

a

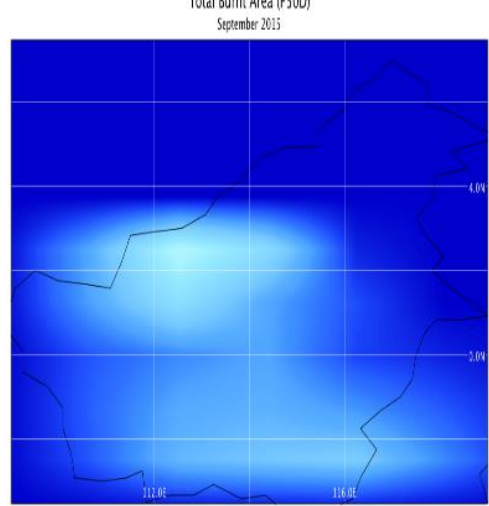

total burnt area fraction (month-1)

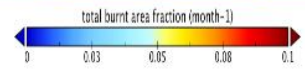

C

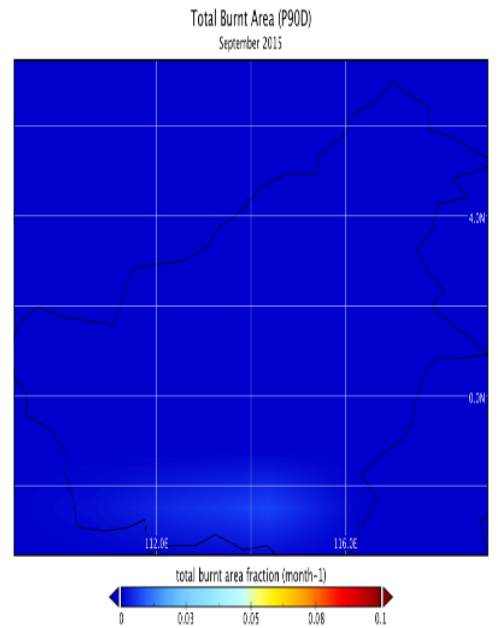

b

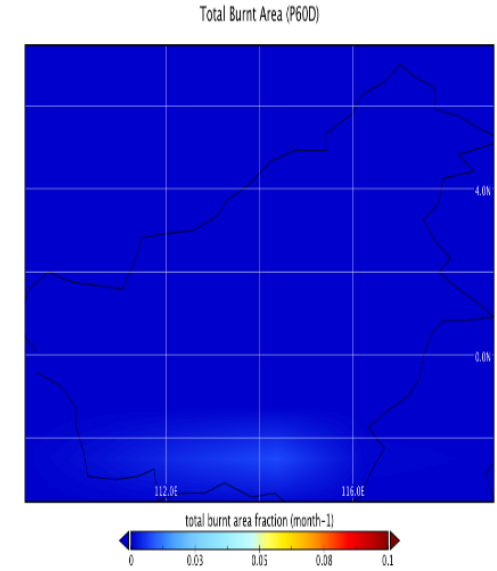

d

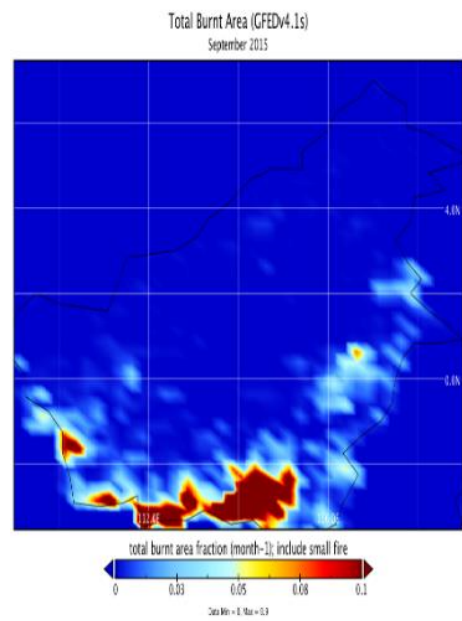

Figure 7. The total burnt area over different scenarios of long-term precipitation. a. an average of 30-days of precipitation, b. an average of 60-days of precipitation, c. an average of 90-days of precipitation, and d. the verification from GFEDv4.1s

\subsection{Peat Carbon Combustion Adjustment}

Apart from the climatic factor that is represented as long-term precipitation, Brasika (2022) 
combustion completeness should be considered as it will vary drastically due to human intervention. In the natural conditions, peatland has the ability to stop peat fire regime as it contains an abundance of water. Unfortunately, human practice of peat drainage reduces its capacity to do so.

\subsubsection{Low Combustion: $18 \%$ combustion completeness}

Li et al. (2013) assumed that in tropical peatlands about $18 \%$ combustion completeness would happen in every peat fire occurrence. As the previous section has shown that the 30-day long-term precipitation produced the most reliable result, this scenario is used to simulate the emitted carbon. Figure 8 shows that natural combustion completeness $(18 \%)$ is used to simulate peat carbon emissions in September 2015. The result shows that the dominant carbon emission is located in the north part of Borneo where the highest emission may reach more than $500 \mathrm{~g} \mathrm{C} \mathrm{m}^{-2}$ month ${ }^{-1}$.

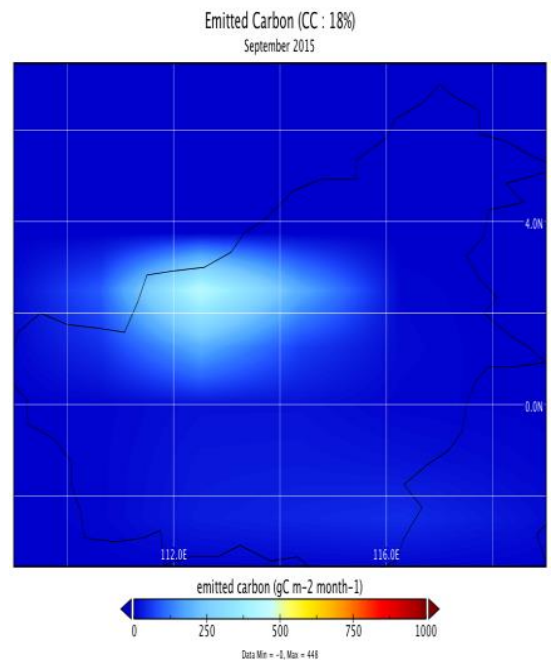

Figure 8. The spatial distribution of carbon emissions in the high El Nino month. Scenario: natural conditions of peat soil; CC $18 \%$.

\subsubsection{High combustion: $50 \%$ combustion completeness}

As mentioned in van der Werf et al. (2006), a minimum of $50 \%$ of soil carbon will be lost in a tropical peat fire due to human-induced drainage. Therefore, the combustion completeness of peat soil was adjusted to see how the human activity of peat drainage might affect the fire. This scenario temporally and spatially produced the same pattern as that in the previous scenario (no-drainage; CC 18\%), but the magnitude of the carbon emission was more than twice as high (Figure 9). The highest carbon emission amounted to more than $1.000 \mathrm{~g} \mathrm{C} \mathrm{m}^{-2}$ month $^{-1}$. 
Emitted Carbon (CC: $50 \%$

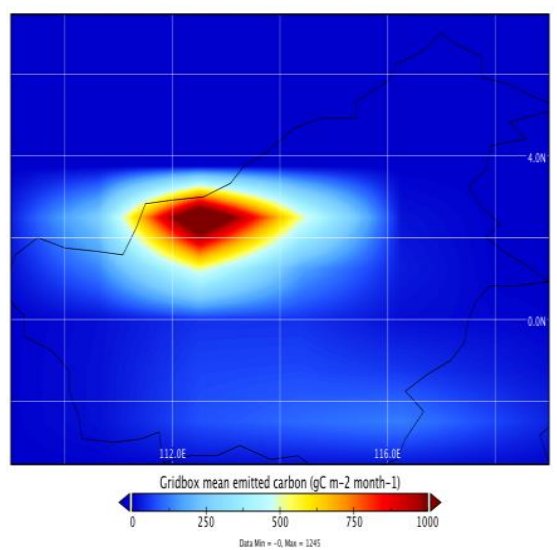

Figure 9. The spatial distribution of carbon emissions in the high El Nino month. Scenario: human-induced drainage of peat; CC $50 \%$

The magnitude of carbon emissions might be well presented by the model, notably in the scenario of $50 \%$ combustion completeness. However, the model failed to figure out the temporal distribution of carbon emissions. Figure 10 shows the overestimating of the model's emitted carbon between January and June, in a period of low/no El Nino that should have the conditions of a low amount of burnt area and a low level of carbon emission. In the second half of the year, the model captured the variability of carbon emissions during the El Nino episode, but the peak of the model's fire regime preceded the real conditions. Unfortunately, the model was also not adequate to simulate the tremendous carbon emission in September 2015, which is estimated at $160,000 \mathrm{~g} \mathrm{C} \mathrm{m}^{2}$ month-1 $^{-1}$, as the model (CC 50\%) simulated a carbon emission of less than $4,000 \mathrm{~g} \mathrm{C} \mathrm{m}^{-2}$ month $^{-1}$.

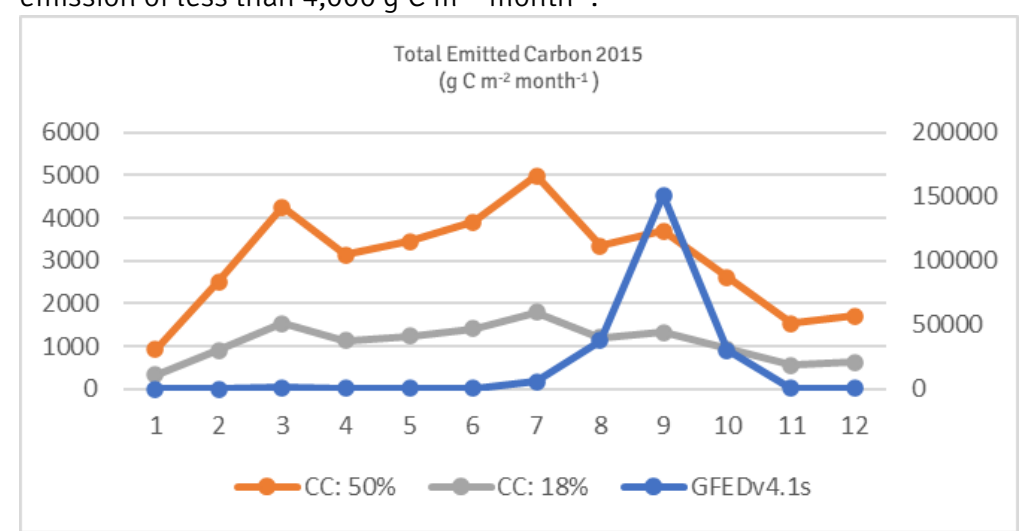

Figure 10. Temporal variability of carbon emissions in 2015. CC 18\%, CC 50\%, verification from GFEDv4.1s. First y-axis is for CC: $50 \%$ and CC: $18 \%$, while second yaxis is for GFEDV4.1s. 


\section{DISCUSSION}

\subsection{Model finding}

The model simulating without peat showed a lower global burnt area in the El Nino period than in the with-peat scenario. This might be affected by the failure of the model to simulate a fire in the tropical region. Hence, the model output was highly affected by the northern high latitude fire. The northern high latitudes, unlike the Equatorial Asia, become wetter, which makes it unlikely for the area to catch a fire (Figure 11). This could explain the low burnt area fraction in the without-peat scenario during the El Nino episode.

This zero burning in tropical regions during the El Nino episode means that the model interprets that a vegetation fire above the ground surface is unlikely to occur naturally (without human intervention) even in the dry condition. The peat, however, is less resilient to climate variability like El Nino. The climate element, notably long-term precipitation, drives the potential of peat to be ignited Someshwar et al. (2007). Thus, peat cannot be neglected in the fire modelling especially in an area that is obviously affected by El Nino.

The peat's contribution was proven when the peat-burning scenario was applied. The size of the burnt area increased significantly from zero to around $4 \times 10^{-8} \mathrm{~s}^{-1}$ in the tropical/equatorial area. The increase in the amount of emitted carbon was a few times higher than the increase in the size of the burnt area as the peat soil contained a large amount of carbon. Although the peat massively contributed to fire, the model failed to simulate the spatial distribution of fire. This was caused by the peat map dataset. The peat fraction in the dataset used is dominantly in the north-west of Borneo Stocker et al. (2017). Meanwhile, the peatland of Borneo is located in the southern region. This research used the 1985 peat map dataset because a more recent dataset was not available.

\section{El Niño and Rainfall}

El Niño conditions in the tropical Pacific are known to shift rainfall patterns in many different parts of the world. Although they vary somewhat from one El Niño to the next, the strongest shifts remain fairly consistent in the regions and seasons shown on the map below.

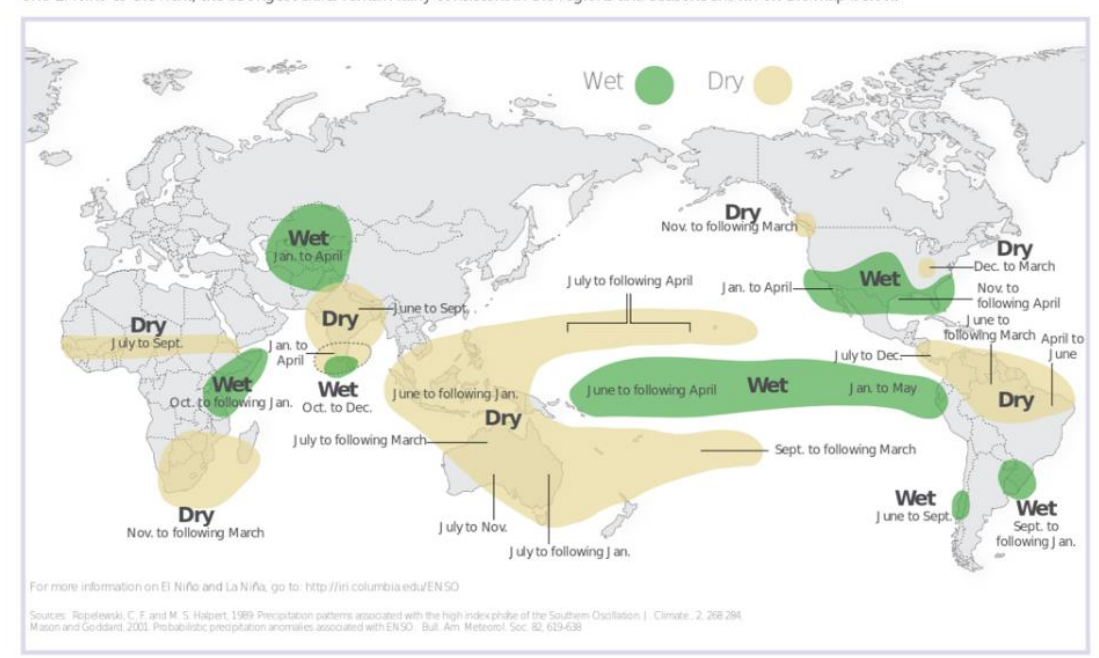

Figure 11. The global impact of El Nino (Barnston, 2014) 
The 60-day and 90-day long-term precipitation scenarios were unsuccessful in simulating the fire distribution. They misrepresented fire in the dominant peat fraction area and underestimated the magnitude of the burnt area. Nevertheless, peat burning was clearly shown in the 30-day long-term precipitation scenario. The average 30-day precipitation $\left(P_{30 d}\right)$ produced a completely different spatial distribution from other scenarios. The dominant burnt peat area was in the peat fraction area. Thus, $P_{30 d}$ might be the best value to quantify the climatic factor in the burnt peat area.

Although the $P_{30 d}$ unsuccessfully simulated the burnt area in the exact location (the actual fire was in the south of Borneo), this scenario proves that the model is capable of modelling the peat fire as it successfully showed the peat fire in the region in which peat was located. Thus, an improvement of the peat dataset will significantly increase the capability of the fire model.

Another crucial variable to be considered is the peat carbon emission. As stated by Cochrane (2003), the fire in Equatorial Asia has less burnt area but a higher carbon emission. This anomaly is likely due to the organic content in the peat soil which is rich in carbon content (Hoojier et al., 2010). The scenario of no human-induced drainage (with $18 \%$ combustion completeness) produced a spatial distribution in the location of peat. However, the magnitude of the emission was quite low.

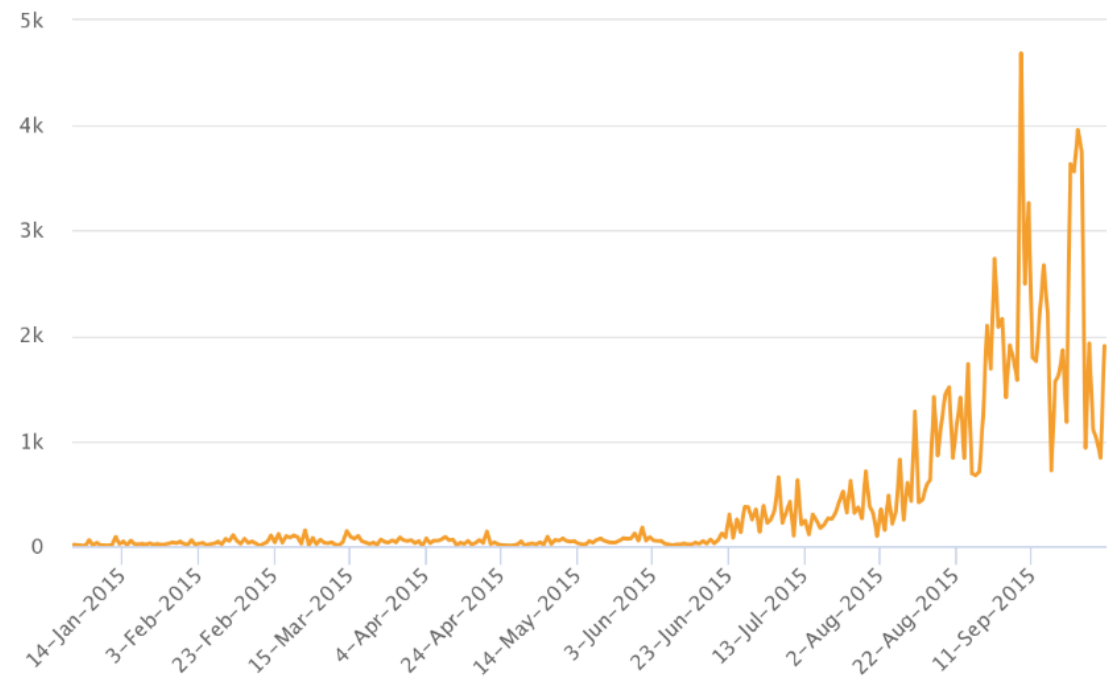

Figure 12. The fire alerts over Indonesia in the 2015 massive fire regime (source: (World Resources Institute, 2016))

The adjustment of combustion completeness successfully improved the magnitude of the emitted carbon. Unfortunately, this remains low compared to the verification data, especially in the peak of fire regime when the emission reached $160,000 \mathrm{~g} \mathrm{C} \mathrm{m}^{-2}$ month$^{-1}$, as the model showed less than $4.000 \mathrm{~g} \mathrm{C} \mathrm{m}^{-2}$ month$^{-1}$. This is because the model utilized a single value of $50 \%$ combustion completeness (CC), which should have varied between different areas. Moreover, $50 \% \mathrm{CC}$ is the minimum value of soil loss following human-induced drainage. The real CC might be much higher (van der Werf, 2006). 
Both scenarios (18\% and 50\%) were able to illustrate the increase in emission in the first stage of El Nino rising (June-July) and the decline towards the end of the El Nino episode (October-December). Nevertheless, they overestimated carbon emissions during the weak El Nino or the starting period of El Nino (January-May), as this period should have zero carbon emission from wildfires. Figure 12 shows the fire alerts over Indonesia from the MODIS dataset. There were no or few fires between January and June 2015. This might be affected by the dependency of peat fire calculation on climatic factors (long-term precipitation). The calculation does not consider the source of ignition such as lightning or human ignition (Li et al., 2013). Therefore, it simulates peat fire when the climate condition is favorable for an ignition, even when there is no ignition.

The model output shows that the peat fire calculation could improve the predictability of fire modelling in the tropical area. Even though all scenarios of longterm precipitation could not afford the real value of fire occurrence on Borneo, the $P_{30 d}$ and human-induced drainage had the most accurate simulation. The sensitivity test proves that the number of days of precipitation is crucial to illustrate the hydrological behavior of peat. Furthermore, the assumption of the homogeneity of combustion completeness provided over-simplified results regarding carbon emission. Despite the lack of details in this modelling, the overall model was able to estimate the actual variability of fires during high El Nino but had a poor simulation during weak/no El Nino.

However, the whole story of the peat hydrological cycle remains covered. Peat soil characteristics are certainly different from those of mineral soil. Hydrological processes control the characteristics of peatland (Soulsby et al., 2006). Labadz et al. (2010) explained that the origin, chemical quality, volume, and variability of the water supply determine the nature of peat, while the existence of water depends upon retaining water.

As rainfall is the main input for peat soil moisture and precipitation or rainfall is crucial to determine the character of a bog Labadz et al. (2010), the prediction of long-term precipitation could be an appropriate approach to avoid future massive fires. This INFERNO modelling could be used as an additional tool to manage potential tropical fires. Although the result lacks in details, the variability of fires is generally well-captured on a regional scale. A more sophisticated approach to estimate fire emissions may be necessary in future modelling. Variations in the carbon content and inorganic content could be significant for emission calculation. Furthermore, this INFERNO model has a simple algorithm that needs low computational resources but is quite accurate, so future development will potentially improve the fire management strategy on a regional or global scale.

\subsection{Constraints and limitations}

There are some assumptions in this model that might affect the ability of the model to simulate the fire properly. Simplification in modelling is essential to produce effective simulations, but some factors could be essential and need to be detailed. Here are some of the limitations in this study: 
Table 2. List of Assumptions and Limitations

\begin{tabular}{|c|c|}
\hline \multicolumn{2}{|r|}{ Assumption \& Limitation } \\
\hline No peat in JULES & $\begin{array}{l}\text { The JULES model provided all the land variables that were required by } \\
\text { the fire model, essentially the soil moisture. Unfortunately, peat soil was } \\
\text { not recognized by JULES. Although the peat soil fraction was added to } \\
\text { the model, the hydrological process was not revealed, whereas peat soil, } \\
\text { unlike mineral soil, has unique characteristics. Thus, this model } \\
\text { assumed that the hydrological cycles of mineral soil and peat soil are } \\
\text { similar. }\end{array}$ \\
\hline Old Peat Map & $\begin{array}{l}\text { The most recent global peat map is from } 1985 \text {. This study found that the } \\
\text { peat soil cover has not changed significantly within the several decades. } \\
\text { However, some irritating fires in tropical areas in these recent years } \\
\text { might have crucially affected the current peat fraction. }\end{array}$ \\
\hline $\begin{array}{l}\text { Organic Content } \\
\text { in Soil }\end{array}$ & $\begin{array}{l}\text { The composition of organic and mineral contents in the soil is important } \\
\text { to simulate the combustion completeness of peat. Other than soil } \\
\text { moisture, inorganic content is a crucial factor in the ignition of peat soil } \\
\text { (Rein, 2016). The composition might vary, but the data of this variable } \\
\text { was not available. The model simplified the factor by using a single } \\
\text { percentage to approach this variable. This is adequate for a global-scale } \\
\text { simulation, but a regional-scale simulation needs more details. }\end{array}$ \\
\hline $\begin{array}{l}\text { Simplification of } \\
\text { Soil Moisture in } \\
\text { Peat Drainage }\end{array}$ & $\begin{array}{l}\text { As mentioned by van der Werf et al. (2006), soil carbon in the peat will be } \\
\text { consumed by } 50 \% \text { at the minimum in the scenario of human-induced } \\
\text { drainage. The loss of the other } 50 \% \text { will vary based on the soil moisture } \\
\text { content. Unfortunately, the relation between soil moisture and } \\
\text { combustion completeness (the soil carbon that would be consumed) was } \\
\text { not well calculated in the paper. Therefore, the model modification } \\
\text { simplified the calculation by using a homogeneous value of } 50 \% \text {. }\end{array}$ \\
\hline $\begin{array}{l}\text { Interaction of } \\
\text { peat fire and } \\
\text { above-ground fire }\end{array}$ & $\begin{array}{l}\text { The model calculated the peat fire and the above-ground fire separately. } \\
\text { It ignored the interaction between them. In fact, the peat fire might have } \\
\text { spread to the vegetation and ignited a new area. This simplification } \\
\text { meant the model cannot approach fire regimes, especially in the peak } \\
\text { when fires easily interact. }\end{array}$ \\
\hline
\end{tabular}

\section{CONCLUSIONS}

The El Nino variability obviously affects wildfires in the tropics, although the correlation of the above-ground fire with El Nino was not well-captured by the model. The peat fire calculation has a key role to improve the model. It showed no fire in the tropical area in the without-peat scenario, but it showed $4 \times 10^{-08} \mathrm{~s}^{-1}$ burnt area when a peat simulation was added.

A formula by Li et al. (2013) suggests the average 60-day long-term precipitation $\left(P_{60 d}\right)$ as the best approach in terms of the climatic factor, but this study finds that the peat fire scenario with the average 30-day long-term precipitation $\left(P_{30 d}\right)$ is more relevant. The burnt area for $P_{60 d}$ was only 0.007 fraction/month, but it improved to 0.04 fraction/month for $P_{30 d}$. Nevertheless, this approach needs further research to investigate the robustness of this factor and the application of the same formula in other tropical/ equatorial regions.

The model simulated the peat fire based on the factor of climate conditions (long-term precipitation), the factor of saturated area (area without water table at the surface or at a higher (evel) and the factor of peat fraction. Unfortunately, it failed to calculate the availability of ignitions in the peatland area. 
The model also illustrated the importance of the drainage of peat in the simulation of tropical fires. Even though the burnt area in the peatland could be captured by the model, the carbon emission would be underestimated if the model did not consider the factor of peat drainage. Two scenarios were applied in this research, namely the natural condition scenario (with $18 \%$ combustion completeness) and the human-induced scenario (with 50\% combustion completeness). The $50 \%$ combustion completeness showed a better model performance, which means that human-induced drainage has a major effect on peat fire. The human drainage practice in the peat is a major cause of the vertical dryness of peat. The fire could reach a deeper layer of the peat due to the drainage, so the fire would consume more fuel in the peatland.

In conclusion, El Nino and peatland are significant drivers in the fire modelling in tropical forests, so they should be considered carefully in simulations. The JULESINFERNO fire model is capable of simulating the tropical fire even if the input data are limited. This model has a potential to be developed for global and regional fire models as it provides high-quality results with few resources. Though the model needs some further modifications, especially in regulating the fire regime with different climate variabilities and realistic peat fire caused by human-induced drainage.

\section{APPENDIXA}

\section{Above-Ground Fire Model}

- Ignitions (I)

There are two main ignitions sources in INFERNO, which are natural ignition $\left(I_{N}\right)$ from lightning and anthropogenic ignition $\left(I_{A}\right)$ based on population density. These ignitions can be set as three different modes.

First is the ubiquitous or constant ignition, the total ignition $\left(\mathrm{I}_{\mathrm{T}}\right)$ is currently calibrated to a global average of $1.67 \mathrm{~km}^{-2} \mathrm{month}^{-1}$. These represent 1.5 ignitions $\mathrm{km}^{-2} \mathrm{month}^{-1}$ of human ignition and 0.17 ignitions $\mathrm{km}^{-2} \mathrm{month}^{-1}$ due to lightning; this number is derived from multi-year annual mean of 2.7 strikes $\mathrm{km}^{-2} \mathrm{year}^{-1}$ (Huntrieser et al., 2008). Second, the human ignition and suppressions remain constant, but the natural ignition may be varied based on cloud-to-ground lightning. Third, the natural and anthropogenic ignition is not constant. In this scenario, the human ignition is derived from population density (PD), see equation (A1), as proposed by Venevsky et al. (2002).

$$
I_{A}=k(P D) P D \alpha
$$

Human ignition is determined by the PD as population density; $k(P D)=6.8 \times P^{-0.6}$ is a function of the varying anthropogenic influence in different population density. This factor considers the characteristics of people in the rural area who interact with the natural ecosystem more frequently; $\alpha=0.03$ is the number of the potential sources of ignition per person per month per $\mathrm{km}^{2}$. As the natural or human ignition has the potential to be suppressed by human, the factor of fires not suppressed (equation (A2)) is:

$$
f N S=7.7\left(0.05+0.9 \times e^{-0.05 P D}\right)
$$

This equation includes the number 7.7 which is the calibration number of fire from the MODIS observations dataset. From this, the total ignitions can be calculated using the equation (A3).

$$
I_{T}=\left(I_{N}+I_{A}\right) f N S /\left(8.64 \times 10^{10}\right)
$$

The fNS for modes 1 and 2 is equal to 1 ; however, the fNS for mode 3 is as in the equation (A2). The divider 8.64 $\times 10^{10}$ converts the ignition from $\mathrm{km}^{-2} \mathrm{month}^{-1}$ to $\mathrm{m}^{-2} \mathrm{~s}^{-1}$. In this research, mode 3 is utilized to produce a dynamic and interactive fire model.

- Flammability (F)

Flammability is adapted from Pechony \& Shindell [2009] to elaborate the Earth Science Model (ESM). The equation is related to the vapor pressure ( $e^{*}$; equation (A4)), fuel load index ( $F L_{\text {pFT; }}$ equation (A5)), soil moisture, $\mathrm{RH}$, and precipitation. The vapor pressure is temperature dependence and is derived from Goff \& Gratch [1946]. The other variables were obtained from the land surface model (JULES) output.

$$
\log _{10}\left(e^{*}\right)=a\left(\frac{T_{S}}{T}-1\right)+b \log _{10}\left(\frac{T_{S}}{T}\right)+c\left(10^{d\left(1-\frac{T_{S}}{T}\right)}-1\right)+f\left(10^{h\left(\frac{T_{S}}{T}-L\right)}-1\right)
$$

The water vapor equation (Equation (4)) utilizes the constant $a=-7.90298, b=5.02808, c=-1.3816 \times 10^{-7}, d=$ $11.344, \mathrm{f}=8.1328 \times 10^{-3}, \mathrm{~h}=-3.49149$ and the water boiling point temperature $\mathrm{Ts}=373.16^{\circ} \mathrm{K}$. Meanwhile, the T represents temperature at a $1.5 \mathrm{~m}$ height in Kelvin. 


$$
F L_{P F T}=\left\{\begin{array}{c}
1 \text { for Fuel }_{\text {high }}<\left(D P M_{C}+\text { Leaf }_{C, P F T)}\right. \\
\frac{\left(D P M_{C}+\text { Leaf }_{C, P F T}-\text { Fuel }_{\text {low }}\right.}{\text { Fuel }_{\text {high }}-\text { for }_{\text {low }} \text { fuel }_{\text {low }} \leq\left(D P M_{C}+\text { Lea }_{C, P F T}\right) \leq \text { Fuel }_{\text {high }}} \\
0 \text { for Fuel }_{\text {low }}>\left(D P M_{C}+\text { Leaf }_{C, P F T}\right)
\end{array}\right.
$$

The Fuel Load varies between Plant Functional Tree (PFT) as the leaf carbon is specific for different PFT. This also determines the carbon in Decomposable Plant Material (DPM) which is assumed that $70 \%$ is available for fire. The amount of FL is in the range between 0 (threshold of Fuel $_{\text {low }}=0.02 \mathrm{kgCm}^{-2}$ ) to 1 (threshold of Fuel high $_{\text {. }}$ $=0.2 \mathrm{kgCm}^{2}$ ) with linear dependent.

$$
\begin{gathered}
F_{P F T}=\left\{\begin{array}{c}
e^{*} e^{-2 R} F L_{P F T}(1-\theta) \text { for } R H_{\text {up }}<R H \\
e^{*} \frac{R H-R H_{\text {low }}}{R H_{\text {up }}-R H_{\text {low }}} e^{-2 R} F L_{P F T}(1-\theta) \text { for } R H_{\text {low }} \leq R H \leq R H_{\text {high }} \mathrm{F}_{\mathrm{PFT}}= \\
0 \text { for } R H_{\text {low }}>R H \\
\mathrm{e}^{*} \mathrm{e}^{-2 \mathrm{R}} \mathrm{FL}_{\mathrm{PFT}}(1-\theta) \text { forRH } \mathrm{Hp}_{\mathrm{up}}<\mathrm{RH}
\end{array}\right. \\
\left\{\begin{array}{c}
\mathrm{e}^{*} \frac{\mathrm{RH}-\mathrm{RH}_{\text {low }}}{\mathrm{RH}_{\text {up }}-\mathrm{RH}_{\text {low }}} \mathrm{e}^{-2 \mathrm{R}} \mathrm{FL}_{\mathrm{PFT}}(1-\theta) \text { forRH } \mathrm{H}_{\text {low }} \leq \mathrm{RH} \leq \mathrm{RH}_{\text {high }} \\
0 \text { forRH } H_{\text {low }}>\mathrm{RH}
\end{array}\right.
\end{gathered}
$$

$\mathrm{RH}$ and $\mathrm{R}$ represent relative humidity (\%) and precipitation ( $\mathrm{mm} /$ day), respectively. The $\mathrm{RH}$ is bound between 0 $\left(\mathrm{RH}_{\text {low }}=10 \%\right)$ and $1\left(\mathrm{RH}_{\text {up }}=90 \%\right)$. Then, the formula is adapted by changing the Leaf Area Index (LAI) with the Fuel Load Index (FL). Lastly, flammability (Equation (A6)) is related to the upper-level (down to $0.1 \mathrm{~m}$ ) soil moisture. $\theta$ represents the fraction of unfrozen soil moisture in saturated area.

\section{Burnt Area (BA)}

The burnt area of the above-ground fire is associated with the average burnt area per fire each PFT, effectively decoupling the fire-spread stage from local meteorology and topography. The average burnt area of each PFT was determined by $0.6,1.4$ and $1.2 \mathrm{~km}^{2}$ for trees, grass, and shrubs, respectively. The sub-categories of these three kinds of PFT were not differentiated. The burnt area calculation (equation (A7)) is as follows:

$$
B A_{P F T}=I_{T} F_{P F T} \overline{B A_{P F T}}
$$

$B A_{P F T}$ is the burnt area for each PFT while $I_{T}$ and $F_{P F T}$ represent the number of fires. Likewise, $B_{P F T}, F_{P F T}$ is also determined by the type of PFT.

\section{Emitted Carbon (EC)}

The emitted carbon (Equation (A8)) is calculated based on the burnt area with specific PFT; the minimum and maximum combustion completeness that can be separated between the leaf $\left(C_{\min }=0.8\right.$ and $\left.C C_{\max }=1.0\right)$ and stem $\left(\mathrm{CC}_{\min }=0.0\right.$ and $\left.\mathrm{CC}_{\max }=0.4\right)$; and the carbon stored in each PFT's leaf or stem.

$$
E C_{P F T}=B A_{P F T} \sum_{\text {leaf }, \text { stem }}^{i}\left(C C_{\text {min }, i}+\left(C C_{\text {max }, i}-C C_{\min , i}\right)(1-\theta)\right) C_{i}
$$

This approach is similar to the Global Fire Emission Database (GFED; [van der Werf et al. [2010]). The differences are that GFED uses more complex representations of soil moisture in different fuel types and only accounts for fires that are observed, while this scheme relies on soil moisture and is much more sensitive to minimum combustion.

Competing interests: The author declare that they have no competing interests.

Acknowledgments: This research is funded by the Indonesian Endowment Fund (LPDP). My highest appreciation for my supervisor Dr. Apostolos Voulgarakis for his patience in giving direction for this research, my mentor Stephane Mangeon who has helped me a lot with the technical aspects and concept of the INFERNO, and Chantele Burton for the insights during my research.

\section{REFERENCES}

Achard, F., Eva, H. D., Stibig, H. J., Mayaux, P., Gallego, J., Richards, T., \& Malingreau, J. P. (2002). Determination of deforestation rates of the world's humid tropical forests. Science, 297(5583), 999-1002. https://doi.org/10.1126/science.1070656

Barnston, A. (2014). How ENSO leads to a cascade of global impacts. Retrieved from https://www.climate.gov/news-features/blogs/enso/how-enso-leads-cascade- 
global-impacts

Best, M. J., Pryor, M., Clark, D. B., Rooney, G. G., Essery, R. L., Ménard, C. B., . . . Harding, R. J. (2011). The Joint UK Land Environment Simulator (JULES), model description - Part 1: Energy and water fluxes, Geoscience Model Development, 4, 677-699. https://doi.org/10.5194/gmd-4-677-2011

Christian, H. J., Blakeslee, R. J., Boccippio, D. J., Boeck, W. L., Buechler, D. E., Driscoll, K. T., ... \& Stewart, M. F. (2003). Global frequency and distribution of lightning as observed from space by the Optical Transient Detector. Journal of Geophysical Research: Atmospheres, 108(D1), ACL-4. https://doi.org/10.1029/2002JD002347

Clark, D. B., Mercado, L. M., Sitch, S., Jones, C. D., Gedney, N., Best, M. J., . . Cox, P. M. (2011). The Joint UK Land Environment Simulator (JULES), model description- Part 2: Carbon fluxes and vegetation dynamics. Geoscience Model Development, 4, 701-722. https://doi.org/10.5194/gmd-4-701-2011

Cochrane, M. A. (2003). Fire science for rainforests. Nature, 421(6926), 913-919. https://doi.org/10.1038/nature01437

Dee, D. P., Uppala, S. M., Simmons, A. J., Berrisford, P., Poli, P., Kobayashi, S., ... \& Vitart, F. (2011). The ERA-Interim reanalysis: Configuration and performance of the data assimilation system. Quarterly Journal of the royal meteorological society, 137(656), 553-597. https://doi.org/10.1002/qj.828

Field, R., van der Werf, G. \& Shen, S. (2009). Human amplification of drought-induced biomass burning in Indonesia since 1960. Nature Geosci, //, 185-188.

Frandsen, W. (1997). Ignition probability of organic soils. Can. J.For. Res. , 27(9), 1471-1477.

Friedlingstein, P., Bopp, L., Ciais, P., Dufresne, J. L., Fairhead, L., LeTreut, H., ... \& Orr, J. (2001). Positive feedback between future climate change and the carbon cycle. Geophysical Research Letters, 28(8), 1543-1546. https://doi.org/10.1029/2000GL012015

Friedlingstein, P., Dufresne, J. L., Cox, P. M., \& Rayner, P. (2003). How positive is the feedback between climate change and the carbon cycle?. Tellus B: Chemical and Physical Meteorology, 55(2),

692-700. https://doi.org/10.3402/tellusb.v55i2.16765

Fuller, D. O. (2006). Tropical forest monitoring and remote sensing: A new era of transparency in forest governance? Singapore Journal of Tropical Geography, 27(1), 15-29. https://doi.org/10.1111/j.1467-9493.2006.00237.x

Giglio, L., Randerson, J. T. \& van der Werf, G. (2013). Analysis of daily, monthly, and annual burned area using the fourth-generation global fire emissions database (GFED4). Journal of Geophysical Research: Biogeosciences, 118(1), 317-328. https://doi.org/10.1002/jgrg.20042

Goff, J. \& Gratch, S. (1946). Low-pressure properties of water from 160 to $212 \mathrm{~F}$. Transactions of the American Society of Heating and Ventilating Engineers, 52, 95-121.

Hantson, S., Arneth, A., Harrison, S. P., Kelley, D. I., Prentice, I. C., Rabin, S. S., ... \& Yue, C. (2016). The status and challenge of global fire modelling. Biogeosciences, 13(11), 3359-3375. https://doi.org/10.5194/bg-13-3359-2016

Hoojier, A., Page, S., Canadell, J., Silvius, M., Kwadijk, J., Wosten, H. \& Jauhiainen. (2010). Current and future CO2 emissions from drained peatlands in Southeast Asia. Biogeosciences, 7(5), 1505-1514. https://doi.org/10.5194/bg-7-1505- 
2010

Huntrieser, H., Schumann, U., Schlager, H., Höller, H., Giez, A., Betz, H. D., ... \& Calheiros, R. (2008). Lightning activity in Brazilian thunderstorms during TROCCINOX: implications for $\mathrm{NO} x$ production. Atmospheric Chemistry and Physics, 8(4), 921-953. https://doi.org/10.5194/acp-8-921-2008

Hurtt, G. C., Chini, L. P., Frolking, S., Betts, R. A., Feddema, J., Fischer, G., ... \& Wang, Y. P. (2011). Harmonization of land-use scenarios for the period 1500-2100: 600 years of global gridded annual land-use transitions, wood harvest, and resulting secondary lands. Climatic change, 109(1), 117-161. https://doi.org/10.1007/s10584-011-0153-2

Labadz, J., Allott, T., Evans, M., Butcher, D., Bilett, M., Stainer, S., . . Hart, R. (2010). Peatland Hydrology. IUCN Hydrology and Restoration Workshop.

Langner, A. \& Siegert, F. (2007). The role of fire on land cover changes in Borneo. Sevilla-Espana Wildfire 2007.

Le Quéré, C., Moriarty, R., Andrew, R. M., Peters, G. P., Ciais, P., Friedlingstein, P., . . Zeng, N. (2015). Global carbon budget 2014. Earth System Science Data, 71), 47-85. https://doi.org/10.5194/essd-7-47-2015

Li, F., Levis, S., \& Ward, D. S. (2013). Quantifying the role of fire in the Earth systemPart 1: Improved global fire modeling in the Community Earth System Model (CESM1). Biogeosciences, 10(4), 2293-2314. https://doi.org/10.5194/bg102293-2013

Liu, J., Bowman, K. W., Schimel, D. S., Parazoo, N. C., Jiang, Z., Lee, M., ... \& Eldering, A. (2017). Contrasting carbon cycle responses of the tropical continents to the 2015-2016 El Niño. Science, 358(6360), 1-7. https://doi.org/10.1126/science.aam5690

Mangeon, S. (2016). Developing and evaluating a global model for landscape fires. [Doctoral Dissertation], Imperial College London. https://doi.org/10.25560/ 48066

Mangeon, S., Voulgarakis, A., Gilham, R., Harper, A., Sitch, S., \& Folberth, G. (2016). INFERNO: a fire and emissions scheme for the UK Met Office's Unified Model. Geoscientific Model Development, 9(8), 2685-2700. https://doi.org/10.5194/gmd-9-2685-2016

National Weather Service. (2015). Cold \& Warm Episodes by Season. Retrieved from http://www.cpc.ncep.noaa.gov/products/analysis_monitoring/ensostuff/ensoye ars.shtml

Page, S. E., Siegert, F., Rieley, J. O., Boehm, H. D. V., Jaya, A., \& Limin, S. (2002). The amount of carbon released from peat and forest fires in Indonesia during 1997. Nature, 420(6911), 61-65. https://doi.org/10.1038/nature01131

Parish, F., Sirin, A., Charman, D., Joosten, H., Minayeva, T., Silvius, M. \& Stringer, L. (2008). Assesment on Peatlands, Biodiversity and Climate Change. Wetlands International. Wageningen: Global Environment Centre.

Pechony, O. \& Shindell, D. (2009). Fire parameterization on a global scale. Journal of Gephysical Research: https://doi.org/10.1029/2009JD011927

Atmospheres, 114(D16).

Rein, G. (2016). Smoldering Combustion. In M. J. Hurley (Ed.), SFPE Handbook of Fire Protection Engineering (Vol. 5). Springer.

Rieley, J. \& Page, S. (2005). Wise Use of Tropical Peatland: Focus on Southeast Asia. ALTERA-Wageningen University and Research Centre and the EU INCO- 
STRAPEAT and RESTORPEAT Partnership.

Siegert, F., Ruecker, G., Hinrichs, A., \& Hoffmann, A. A. (2001). Increased damage from fires in logged forests during droughts caused by El Nino. Nature, 414(6862), 437-440. https://doi.org/10.1038/35106547

Someshwar, S., Boer, R. \& Conrad, E. (2007). World Resources Report Case Study. Managing Peatland Fire Risk in Central Kalimantan, Indonesia. World Resources Report.

Soulsby, C., Tetzlaff, A., Rodgers, P., Dunn, S. \& Waldron, S. (2006). Runoff processes, stream water residence times and controlling landscape characteristics in a mesoscale catchment: An initial evaluation. Journal of Hydrology, 325, 197-221.

Stocker, B. D., Spahni, R., \& Joos, F. (2014). DYPTOP: a cost-efficient TOPMODEL implementation to simulate sub-grid spatio-temporal dynamics of global wetlands and peatlands. Geoscientific Model Development, 7(6), 3089-3110. https://doi.org/10.5194/gmd-7-3089-2014

Stocker, B. D., Yu, Z., Massa, C., \& Joos, F. (2017). Holocene peatland and ice-core data constraints on the timing and magnitude of $\mathrm{CO} 2$ emissions from past land use. Proceedings of the National Academy of Sciences, 114(7), 1492-1497. https://doi.org/10.1073/pnas.1613889114

Trigg, S. N., Curran, L. M., \& McDonald, A. K. (2006). Utility of Landsat 7 satellite data for continued monitoring of forest cover change in protected areas in Southeast Asia. Singapore Journal of Tropical Geography, 27(1), 49-66. https://doi.org/10.1111/j.1467-9493.2006.00239.x

van der Werf, G., Randerson, J., Giglio, L., Collatz, G., Kasibhatla, P. \& Arellano Jr., A. (2006). Interannual variability in global biomass burning emissions from 1997 to 2004. Atmospheric Chemistry and Physics, 6(11), 3423-3441. https://doi.org/10.5194/acp-6-3423-2006

van der Werf, G. R., Randerson, J. T., Giglio, L., Collatz, G. J., Mu, M., Kasibhatla, P. S., ... \& van Leeuwen, T. T. (2010). Global fire emissions and the contribution of deforestation, savanna, forest, agricultural, and peat fires (1997-2009). Atmospheric chemistry and physics, 10(23), 11707-11735. https://doi.org/10.5194/acp-10-11707-2010

Venevsky, S., Thonicke, K., Sitch, S., \& Cramer, W. (2002). Simulating fire regimes in human-dominated ecosystems: Iberian Peninsula case study. Global Change Biology, 8(10), 984-998. https://doi.org/10.1046/j.1365-2486.2002.00528.x

Wooster, M. J., Perry, G. L. W., \& Zoumas, A. (2012). Fire, drought and El Niño relationships on Borneo (Southeast Asia) in the pre-MODIS era (1980-2000). Biogeosciences, 9(1), 317-340. https://doi.org/10.5194/bg-9-317-2012

World Resources Institute. (2016, March 21). globalforestwatch.org. Retrieved from http://fires.globalforestwatch.org/report/index.html\#aoitype=ISLAND\&dates=fY ear-2016!fMonth-3!fDay-14!tYear-2016!tMonth-3!tDay-21\&aois=Sulawesi! Maluku!Lesser\%20Sunda!Java!Papua!Kalimantan!Sumatra 